\title{
KEBERLANJUTAN SOSIAL GATED COMMUNITY THE TAMAN DAYU DI KABUPATEN PASURUAN
}

\author{
The Social Sustainability of Gated Community the Taman Dayu in \\ Pasuruan Regency
}

\author{
Istifada Alhidayatus Sibyan ${ }^{1}$, Delik Hudalah²
}

Diterima: 18 Juli 2018

Disetujui: 3 Agustrus 2018

\begin{abstract}
Abstrak: Keberlanjutan sosial penting dikaji untuk dapat menggambarkan secara utuh isu-isu sosial gated community. Keberlanjutan sosial dalam penelitian ini merepresentasikan kondisi dimensi sosial yang berkelanjutan. Kondisi ideal tersebut menggambarkan tidak adanya permasalahan sosial akibat gated community, terutama segregasi dan ketimpangan. Kondisi ini dapat dicapai dengan adanya modal dan integrasi sosial. Penelitian ini bertujuan mengetahui karakteristik dan keberlanjutan sosial gated community the Taman Dayu di Kecamatan Prigen, Kabupaten Pasuruan. Gated community the Taman Dayu merupakan gated community terbesar di Kabupaten Pasuruan yang kemungkinan memiliki dampak yang signifikan bagi kawasan di sekitarnya. Keberlanjutan sosial ditinjau dari dua indikator, yaitu modal sosial (jaringan sosial, kepercayaan dan resiprositas) serta integrasi sosial (sudut pandang terhadap pemisahan sosial maupun spasial serta aksesibilitas terhadap fasilitas) yang datanya diperoleh melalui survei primer dengan menggunakan kuisioner. Keduanya diukur dengan menggunakan metode indeks komposit untuk dapat menilai tingkat keberlanjutan sosial. Hasil analisis menunjukkan adanya indikasi keberlanjutan sosial gated community the Taman Dayu. Hasil penelitian ini diharapkan dapat menjadi bahan masukan kebijakan pengembangan wilayah yang terintegrasi dengan pembangunan perumahan untuk mewujudkan pembangunan yang berkelanjutan.
\end{abstract}

Keyword in Bahasa: gated community, integrasi sosial, ketimpangan, modal sosial, segregasi.

\begin{abstract}
The concept of social sustainability can describe the social issues that emerge surrounding gated community. Social sustainability in this study represents the sustainability of social dimension. It refers to the absence of social problems in gated community, especially segregation and inequality. This could be achieved by promoting social capital and social integration. This study aims to asess social capital, social integration and social sustainability of gated community the Taman Dayu in Pasuruan Regency. The social sustainability in this study is assessed by using several indicators including social capital (social network, trust and reciprocity) and social integration (perspective on social and spatial segregation and accessibility to facility). The data was obtained through questionnaire survey and analyzed by using composite index. The study reveals that gated community the Taman Dayu shows a moderate level of social sustainability, which means that the social capital and social integration need to be improved.
\end{abstract}

Keywords: gated community, inequality, segregation, social capital, social integration

\footnotetext{
${ }^{1}$ Sekolah Arsitektur Perencanaan dan Pengembangan Kebijakan, Institut Teknologi Bandung

${ }^{2}$ Pusat Penelitian Infrastruktur dan Kewilayahan, Institut Teknologi Bandung
} 


\section{PENDAHULUAN}

Gated community bukan merupakan hal baru dalam bidang perencanaan wilayah dan kota. Gated community mulai banyak diteliti sejak tahun 1990-an. Bahkan pemikiran tentang gated community sudah ada sejak munculnya fenomena pembangunan perumahan ekslusif oleh pengembang tahun 1980-an. Atkinson \& Blandy, 2005 menjelaskan gated community sebagai cluster perumahan tanpa adanya akses publik dari luar kawasan perumahan yang biasanya dibatasi oleh dinding atau pagar dan dilengkapi dengan berbagai fasilitas. Lingkup penelitian gated community sangat luas dan telah banyak diteliti dari berbagai bidang ilmu pengetahuan seperti ilmu sosial dan politik, sosiologi, perencanaan kota dan ilmu ekonomi. Hal tersebut menunjukkan adanya kompleksitas yang tinggi dalam mempelajari gated community.

Kabupaten Pasuruan sebagai wilayah suburban metropolitan Gerbangkertosusila memiliki nilai strategis diantaranya lokasinya sebagai penghubung Kota Surabaya dan Malang menjadi daya tarik pengembang membangun gated community. Laju pertumbuhan penduduk Kabupaten Pasuruan juga termasuk paling tinggi diantara wilayah suburban metropolitan Gerbangkertosusila lainnya (0.85\% per tahun). Hal ini perlu mendapat perhatian terkait kebutuhan penyediaan perumahan yang juga akan semakin meningkat, termasuk yang berupa gated community. Gated community terbesar di Kabupaten Pasuruan adalah the Taman Dayu. The Taman Dayu sebagai gated community terbesar di Kabupaten Pasuruan memiliki potensi menghasilkan dampak yang lebih besar sehingga dikhawatirkan dapat menyebabkan permasalahan yang lebih kompleks.

The Taman Dayu dibangun pada tahun 2007 dengan luas 600 hektar dan terdiri dari 26 cluster perumahan. The Taman Dayu merupakan perumahan eksklusif yang dibatasi oleh bentang alam, dinding dan pagar. Ditinjau dari ukurannya, the Taman Dayu termasuk gated community tipe kota yang didalamnya terdapat CBD, cluster perumahan dan berbagai fasilitas pendukung. Sementara ditinjau dari sifat 'pemagarannya', the Taman Dayu termasuk kombinasi tipologi jalan berpagar penuh dan kawasan entry terbatas serta berpenjaga. Tipologi ini ditandai pagar atau dinding yang memisahkan kawasan dari lingkungan sekitarnya, namun jaringan jalan menuju zona-zona tertentu tetap terbuka (Grant \& Mittelsteadt, 2004).

Secara umum the Taman Dayu memiliki fitur utama gated community berupa dinding atau pagar yang membatasi akses kawasan. Keberadaan dinding atau pagar seringkali menjadi simbol pemisah antara gated community dengan lingkungan sekitarnya (Roitman, 2010; Widhyharto, 2009; Grant \& Mittelsteadt, 2004). Ditinjau dari aspek sosial, gated community the Taman Dayu merupakan masyarakat golongan menengah ke atas dengan gaya hidup modern. Di sisi lain masyarakat sekitar the Taman Dayu umumnya adalah masyarakat golongan menengah ke bawah dengan gaya hidup tradsional. Hal ini mengindikasikan adanya segregasi sosial yang oleh Vesselinov, Cazessus, \& Falk (2007) dianggap berdampak pada munculnya disintegrasi, ketimpangan dan ketegangan sosial.

Adanya kemungkinan terjadi berbagai permasalahan akibat keberadaan the Taman Dayu sebagai gated community dapat menjadi indikasi pembangunan gated community yang belum berkelanjutan secara sosial. Lebih lanjut gated community the Taman Dayu yang tidak berkelajutan dapat meningkatkan kemungkinan terjadinya permasalahan sebagaimana diuraikan sebelumnya. Oleh karena itu penelitian ini mencoba mengkaji keberlanjutan sosial gated community the Taman Dayu menggunakan pendekatan kuantitatif dengan metode indeks komposit sebagai upaya preventif sekaligus minimalisir berbagai permasalahan sosial. 


\section{METODE}

Penelitian ini merupakan penelitian lapangan (field research) yang menggunakan pendekatan campuran kualitatif dan kuantitatif (mixed methods). Data yang digunakan terdiri dari data kuantitatif dan kualitatif yang analisisnya menggunakan analisis kuantitatif.

\section{Wilayah Studi}

Gated community yang dimaksud dalam penelitian ini adalah kawasan the Taman Dayu yang berada di Kecamatan Prigen Kabupaten Pasuruan, Provinsi Jawa Timur (gambar 1). Pertimbangan penentuan lokasi didasarkan pada 4 kriteria, yaitu kriteria letak, ukuran, kondisi lingkungan sekitar dan tipologi yang mana the Taman Dayu memenuhi keempat kriteria tersebut.

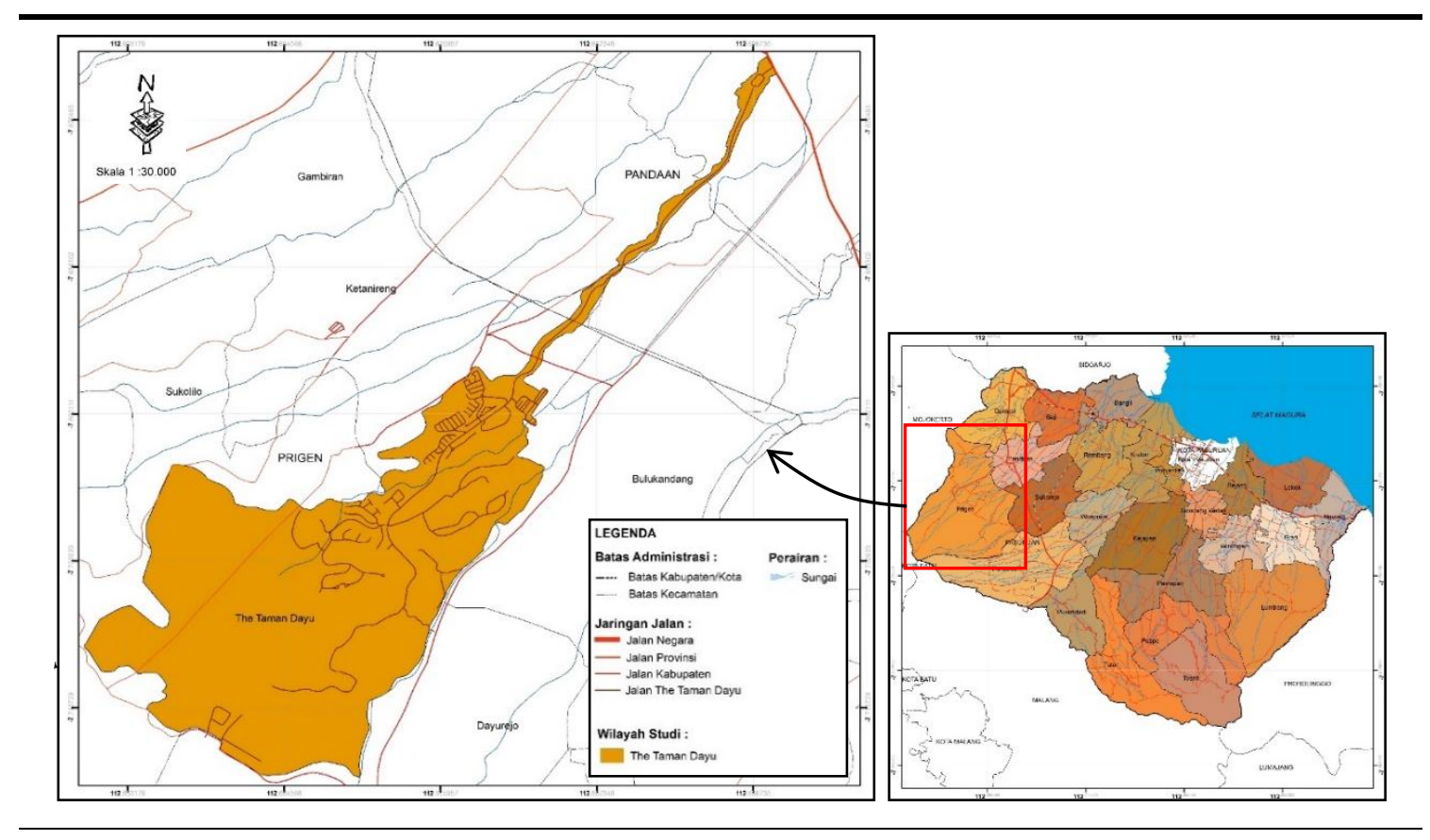

\section{Gambar 1. Peta Wilayah Studi}

\section{Data dan metode analisis}

Dimensi sosial cukup sulit diterjemahkan ke dalam indikator keberlanjutan gated community karena sifatnya kebanyakan sulit diukur. Banyak akademisi yang berusaha membangun kerangka pemahaman terhadap keberlanjutan sosial sebagai bagian dari dimensi pembangunan berkelanjutan. Keberlanjutan sosial dalam penelitian ini lebih menekankan pada kondisi di mana tidak ada permasalahan sosial terkait gated community yang selanjutnya merujuk pada modal dan integrasi sosial. Modal sosial dapat diukur dari tiga komponen utamanya, yaitu jaringan, kepercayaan dan resiprositas (Stone, 2001; Fukuyama, 1995; Putnam, 1993). Sementara integrasi sosial dapat dipahami sebagai wujud dari proses menyatunya seluruh lapisan masyarakat dengan identitas beragam dan didalamnya terdapat kerjasama sehingga dapat menciptakan kehidupan sosial yang harmonis (Cruz-Saco, 2008; Munandar, 2001). Integrasi sosial dalam penelitian ini dipandang sebagai wujud penyatuan dua kelompok berbeda (masyarakat gated community dengan ungated community). Penyatuan ini dilihat dari sudut pandang terhadap pemisahan dan aksesibilitas terhadap fasilitas. 
Indikator yang dikembangkan untuk mengukur kerbelanjutan sosial gated community berasal dari multidimensi turunan modal dan integrasi sosial. Dimensi tersebut dapat diklasifikasikan menjadi jaringan sosial, kepercayaan, resiprositas dan integrasi sosial (tabel 1).

Tabel 1. Dimensi Keberlanjutan Sosial Gated Community

\begin{tabular}{|c|c|c|c|}
\hline No & Indikator & Parameter & Sumber Pustaka \\
\hline A & \multicolumn{3}{|l|}{ Jaringan Sosial } \\
\hline \multirow[t]{2}{*}{1} & Interaksi & 1. Urusan pribadi & \multirow[t]{2}{*}{ (Stone, 2001) } \\
\hline & $\begin{array}{l}\text { dengan } \\
\text { institusi }\end{array}$ & 2. Urusan organisasi & \\
\hline 2 & $\begin{array}{l}\text { Partisipasi } \\
\text { formal }\end{array}$ & $\begin{array}{l}\text { 1. Partisipasi di lingkungan gated community } \\
\text { 2. Partisipasi di lingkungan ungated community }\end{array}$ & $\begin{array}{l}\text { (Baum, C, Palmer, } \\
\text { Murray, \& Bush, } \\
\text { 2000); (Krishna \& } \\
\text { Shrader, 1999) }\end{array}$ \\
\hline 3 & $\begin{array}{l}\text { Partisipasi } \\
\text { informal }\end{array}$ & $\begin{array}{l}\text { 1. Partisipasi di lingkungan gated community } \\
\text { 2. Partisipasi di lingkungan ungated community }\end{array}$ & \multirow{2}{*}{$\begin{array}{l}\text { (Stone, 2001); } \\
\text { (Baum et al., 2000) } \\
\text { (Salcedo \& Torres, } \\
\text { 2002); (Stone, } \\
\text { 2001); (Baum et al., } \\
\text { 2000) }\end{array}$} \\
\hline 4 & $\begin{array}{l}\text { Partisipasi } \\
\text { sosial }\end{array}$ & $\begin{array}{l}\text { 1. Jumlah masyarakat ungated community yang dikenal } \\
\text { 2. Jumlah masyarakat gated community yang dikenal } \\
\text { 3. Frekuensi mengunjungi tetangga di lingkungan gated community } \\
\text { 4. Frekuensi mengunjungi tetangga di lingkungan ungated } \\
\text { community }\end{array}$ & \\
\hline 5 & $\begin{array}{l}\text { Partisipasi } \\
\text { publik }\end{array}$ & $\begin{array}{l}\text { 1. Partisipasi di lingkungan gated community } \\
\text { 2. Partisipasi di lingkungan ungated community }\end{array}$ & \multirow[t]{2}{*}{ (Stone, 2001) } \\
\hline B & \multicolumn{2}{|l|}{ Kepercayaan } & \\
\hline 6 & $\begin{array}{l}\text { Kepercayaan } \\
\text { khusus }\end{array}$ & $\begin{array}{l}\text { 1. Kesediaan menjamu tetangga } \\
\text { 2. Kesediaan meminta bantuan tetangga }\end{array}$ & $\begin{array}{l}\text { (Stone, } 2001 \text { ); } \\
\text { (Onyx \& Bullen, } \\
\text { 2000). }\end{array}$ \\
\hline 7 & $\begin{array}{l}\text { Kepercayaan } \\
\text { umum }\end{array}$ & $\begin{array}{l}\text { 1. Keamanan lingkungan } \\
\text { 2. Kesediaan membantu orang asing } \\
\text { 3. Kesediaan menjamu orang asing } \\
\text { 4. Kenyamanan terhadap orang asing }\end{array}$ & $\begin{array}{l}\text { (Grant } \quad \& \\
\text { Mittelsteadt, 2004); } \\
\text { (Onyx \& Bullen, } \\
2000 \text { ) }\end{array}$ \\
\hline 8 & $\begin{array}{l}\text { Kepercayaan } \\
\text { institusional }\end{array}$ & $\begin{array}{l}\text { 1. Urusan administrasi } \\
\text { 2. Mediasi perselisihan } \\
\text { 3. Urusan kegiatan sosial }\end{array}$ & \multirow[t]{2}{*}{ (Stone, 2001) } \\
\hline C & \multicolumn{2}{|l|}{ Resiprositas } & \\
\hline 9 & Norma & $\begin{array}{l}\text { 1. Kepedulian terhadap warga lingkungan yang sama } \\
\text { 2. Kepedulian terhadap warga lingkungan yang berbeda } \\
\text { 3. Kemudahan dibantu warga lingkungan yang sama } \\
\text { 4. Kemudahan dibantu warga lingkungan yang berbeda } \\
\text { 5. Kontribusi terhadap kegiatan sosial di lingkungan tempat tinggal } \\
\text { 6. Kontribusi terhadap kegiatan sosial di lingkungan sekitar }\end{array}$ & $\begin{array}{l}\text { (Krishna \& Shrader, } \\
\text { 1999) }\end{array}$ \\
\hline 10 & Perilaku & $\begin{array}{l}\text { 1. Mendapat bantuan tetangga lingkungan yang sama } \\
\text { 2. Mendapat bantuan tetangga lingkungan yang berbeda } \\
\text { 3. Membantu tetangga lingkungan yang sama } \\
\text { 4. Membantu tetangga lingkungan yang berbeda } \\
\text { 5. Minat bekerjasama }\end{array}$ & \multirow{2}{*}{$\begin{array}{l}\text { (Roitman, 2010); } \\
\text { (Salcedo \& Torres, } \\
\text { 2002); (Stone, } \\
\text { 2001); (Onyx \& } \\
\text { Bullen, 2000). } \\
\text { (Stone, 2001) }\end{array}$} \\
\hline 11 & Harapan & $\begin{array}{l}\text { 1. Alasan membantu warga lingkungan yang sama } \\
\text { 2. Alasan membantu warga lingkungan yang berbeda }\end{array}$ & \\
\hline $\mathrm{D}$ & Integrasi Sosial & & \\
\hline 12 & $\begin{array}{l}\text { Pemisahan } \\
\text { sosial/spasial }\end{array}$ & $\begin{array}{l}\text { 1. Perbedaan yang membagi masyarakat } \\
\text { 2. Preferensi keragaman tetangga }\end{array}$ & $\begin{array}{l}\text { (Salcedo \& Torres, } \\
\text { 2002); (Krishna \& } \\
\text { Shrader, 1999). }\end{array}$ \\
\hline 13 & $\begin{array}{l}\text { Aksesibilitas } \\
\text { terhadap } \\
\text { fasilitas }\end{array}$ & $\begin{array}{l}\text { 1.Aksesibilitas terhadap Taman di lingkungan ungated } \\
\text { community } \\
\text { 2.Aksesibilitas terhadap Taman di lingkungan gated community } \\
\text { 3. Aksesibilitas terhadap sarana olahraga gated community } \\
\text { 4. Aksesibilitas terhadap sarana olahraga ungated community } \\
\text { 5. Aksesibilitas terhadap sarana peribadatan ungated community } \\
\text { 6. Aksesibilitas terhadap sarana perdagangan ungated community } \\
\text { 7. Aksesibilitas terhadap sarana perdagangan gated community }\end{array}$ & $\begin{array}{l}\text { (Roitman, 2010); } \\
\text { (Salcedo \& Torres, } \\
\text { 2002). }\end{array}$ \\
\hline
\end{tabular}


Data tentang indikator keberlanjutan sosial diperoleh dari persepsi masyarakat the Taman Dayu yang dihimpun melalui survei kuisioner (responden adalah populasi the Taman Dayu sebanyak 50 rumah tangga). Data dianalisis menggunakan indeks komposit untuk menilai indeks modal, integrasi dan keberlanjutan sosial. Adapun tahapan analisis merujuk pada Baffoe \& Mutisya (2015), yaitu: pertama menentukan dimensi, indikator dan parameter yang diberi nilai dalam skala ordinal (skor jawaban ya adalah 1 dan tidak adalah 0 ). Kedua menghitung nilai setiap parameter menggunakan persamaan 1. Ketiga, menghitung nilai indikator menggunakan persamaan 2. Keempat, menghitung keberlanjutan sosial gated community menggunakan persamaan 3. Kelima, mengklasifikasikan keberlanjutan sosial gated community yaitu: $0-0,33$; 0,34-0,66 dan 0,67 - 1,00 masing-masing rendah, sedang dan tinggi (Baffoe \& Mutisya, 2015; Surjono, Sudikno, \& Ridhoni, 2017).

$$
\begin{aligned}
& \mathrm{P}=\mathrm{Ya} \% \mathrm{X} 1+\text { Tidak } \% \mathrm{X} 0 \\
& I=\sum_{i=0}^{i} \frac{p_{i}}{N i} \quad \ldots \ldots \ldots \ldots \ldots \ldots \ldots \ldots
\end{aligned}
$$$$
\text { (persamaan 1) }
$$

$$
\mathrm{SS}=(\mathrm{Ij}+\mathrm{Ik}+\mathrm{Ir}+\mathrm{Ii}) / 4
$$

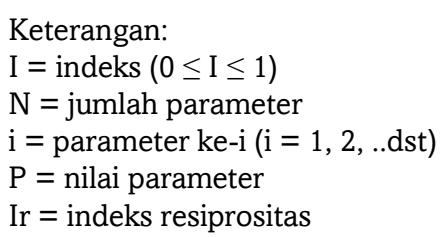

$$
\begin{aligned}
& \text { Ik = indeks kepercayaan } \\
& \mathrm{Ii}=\text { indeks integrasi sosial } \\
& \mathrm{Ij}=\text { indeks jaringan } \\
& \mathrm{SS}=\text { keberlanjutan sosial }
\end{aligned}
$$

\section{HASIL DAN PEMBAHASAN}

Gated community the Taman Dayu secara administrasi masuk dua wilayah kecamatan di Kabupaten Pasuruan, yaitu Kecamatan Prigen dan Kecamatan Pandaan. Kawasan the Taman Dayu memiliki luas wilayah mencapai 600 Ha yang terdiri dari CBD, fasilitas olahraga dan rekreasi, fasilitas pendidikan, hotel serta 26 cluster perumahan seperti yang dapat dilihat pada gambar 2. Kawasan the Taman Dayu secara geografis memiliki letak yang strategis, yaitu berada pada jalur penghubung Kota Malang dengan Kota Surabaya dan merupakan kawasan suburban metropolitan Gerbangkertosusila.

\section{Karakteristik gated community the Taman Dayu}

Kawasan the Taman Dayu sebagai gated community memiliki ciri adanya limitasi akses. Berdasarkan hasil observasi diketahui terdapat beberapa fitur yang menunjukkan fungsi limitasi akses tersebut (gambar 3). Pertama adalah adanya pembatas kawasan berupa dinding, pagar, sawah, hutan, sungai dan RTH. Kombinasi pembatas kawasan alami dan buatan termasuk jenis gated community jalan berpagar penuh. Fitur alami seperti sawah, hutan dan sungai dapat mengurangi kebutuhan pemagaran buatan. Menurut (Grant \& Mittelsteadt, 2004), fitur tersebut tidak mencegah akses orang luar gated community, tetapi dapat mengatur derajat kesulitan aksesibilitas serta mengatur jarak fasilitas yang tidak dapat digunakan bersama dengan masyarakat di luar gated community. Hal ini sesuai dengan kondisi eksisting yang ditemukan pada kawasan the Taman Dayu, yang mana pada area bukan hunian memiliki pembatas alami. Masyarakat di luar the Taman Dayu dapat mengakses area-area tersebut tetapi ada kontrol terhadap aksesibilitas dengan tingkat kesulitan akses jika melewati fitur-fitur alami.

Kedua adalah keberadaan penjaga atau petugas keamanan, yang secara umum bertugas menjaga keamanan kawasan. Bentuk penjagaan yang dilakukan petugas keamanan the Taman Dayu berupa patroli, penjagaan pada pos satpam dan pemeriksaan 
identitas bagi masyarakat di luar the Taman Dayu yang akan memasuki area perumahan, yang semuanya merupakan bentuk limitasi akses. Hal tersebut menunjukkan bahwa ada kontrol terhadap aksesibilitas kawasan gated community. Ketiga adalah adanya fitur keamanan lainnya berupa portal, polisi tidur dan kamera pengawas. Sesuai dengan pendapat (Grant \& Mittelsteadt, 2004) bahwa keberadaan fitur keamanan semacam ini dapat menciptakan keraguan dan ketidaknyamanan (perasaan tidak diinginkan) bagi orang luar gated community, karena ada tujuan mengontrol aksesibilitas kawasan.

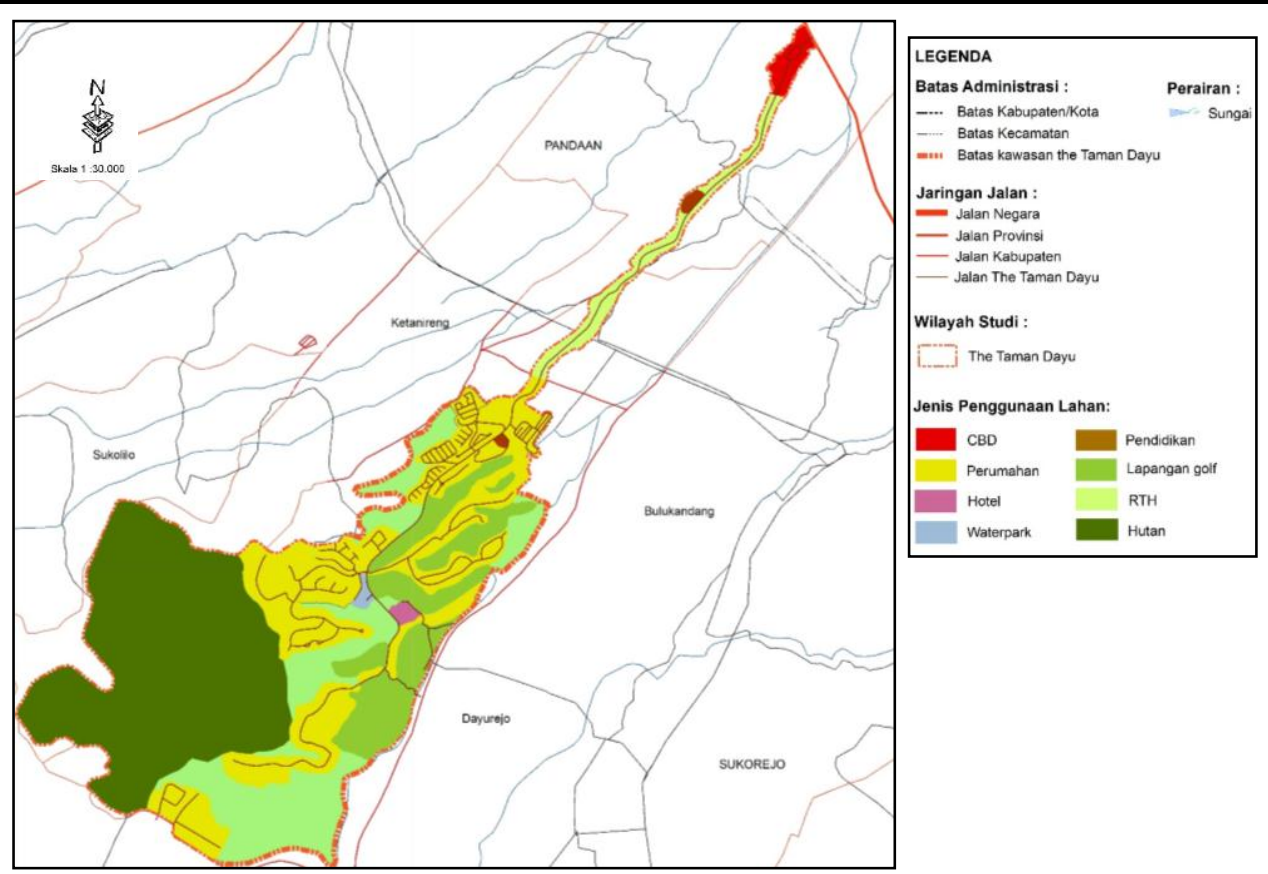

Sumber: Masterplan the Taman Dayu, 2017

Gambar 2. Siteplan the Taman Dayu

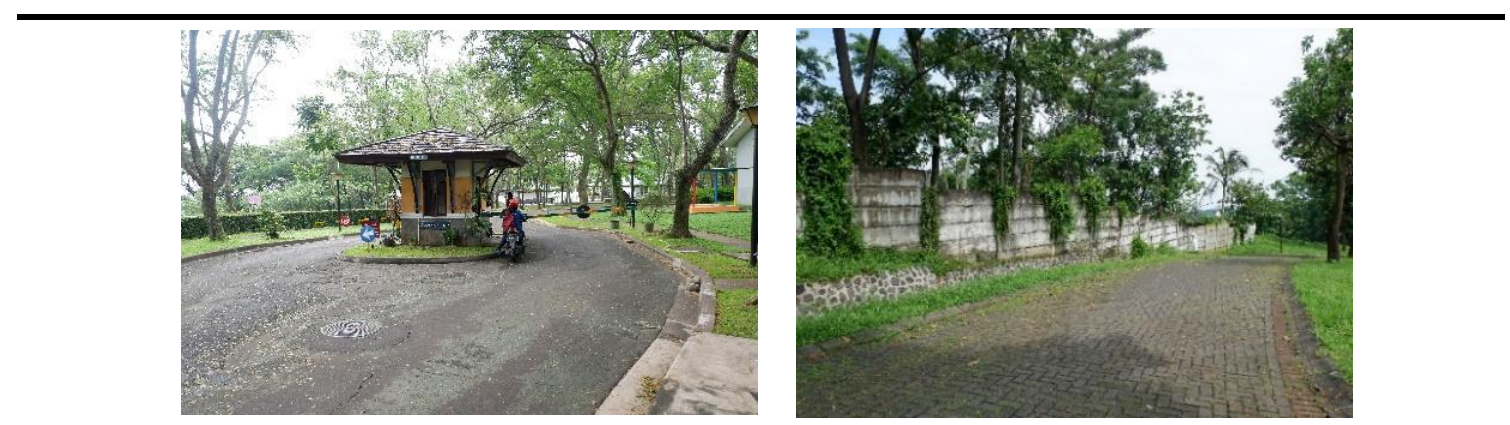

Sumber: Survei Primer, 2018

\section{Gambar 3. Fitur Pemagaran dan Limitasi Akses Kawasan}

Aspek lain yang membedakan gated community dengan permukiman swadaya adalah ketersediaannya fasilitas kawasan yang lebih lengkap. Pada gated community the Taman Dayu, fasilitas tertentu masih dapat diakses oleh non penghuni, diantaranya CBD, taman bermain, fasilitas rekreasi, pendidikan, olahraga dan hotel serta jaringan jalan kawasan. Adanya pemanfaatan fasilitas bersama dapat menjadi wadah kedua kelompok 
masyarakat untuk berinteraksi (Yuliastuti \& Tanjung, 2011). Lebih lanjut hasil interaksi dalam waktu lama akan menghasilkan jaringan, pola kerjasama, pertukaran sosial dan rasa saling percaya, termasuk nilai dan norma yang mendasari hubungan sosial yang disebut modal sosial (Ibrahim, 2006).

Ditinjau dari aspek sosial ekonomi, masyarakat the Taman Dayu memiliki tingkat pendidikan tinggi dibandingkan dengan masyarakat sekitarnya. Sebanyak $64 \%$ masyarakat the Taman Dayu memiliki tingkat pendidikan terakhir sarjana, sedangkan masyarakat sekitarnya lebih didominasi oleh masyarakat dengan tingkat pendidikan SD dan SMA. Sebanyak 72\% masyarakat memiliki pendapatan lebih dari Rp 4,000,000 dengan mata pencaharian dominan adalah pegawai swasta. Hal ini menghasilkan homogenitas ekonomi masyarakat gated community yang umumnya merupakan golongan menengah ke atas dan menciptakan ketimpangan dengan masyarakat sekitarnya.

\section{Modal Sosial gated communitythe Taman Dayu}

Modal sosial dalam penelitian ini ditinjau dari jaringan sosial, kepercayaan dan resiprositas. Berdasarkan analisis terhadap indikator-indikator modal sosial, maka dihitung nilai indeks modal sosial dalam konteks keberlanjutan sosial gated community. Adapun nilai indeks modal sosial tersebut sebesar 0.42 dan termasuk kategori sedang (tabel 2).

Tabel 2. Analisis Modal Sosial

\begin{tabular}{ll}
\hline \multicolumn{1}{c}{ Dimensi } & Nilai \\
\hline Jaringan sosial & 0.26 \\
Kepercayaan & 0.33 \\
Resiprositas & 0.67 \\
\hline \multicolumn{1}{c}{ Nilai Indeks } & $\mathbf{0 . 4 2}$ \\
\hline
\end{tabular}

Nilai indeks jaringan sosial masyarakat the Taman Dayu sebesar 0.26. Nilai ini mengandung makna bahwa masyarakat the Taman Dayu memiliki interaksi institusi, partisipasi publik dan sosial serta partisipasi formal dan informal yang rendah. Rendahnya interaksi masyarakat the Taman Dayu dengan berbagai institusi dapat disebabkan oleh preferensi masyarakat dalam memilih institusi. Rendahnya partisipasi formal dan informal masyarakat dipengaruhi oleh rendahnya keterlibatan dalam komunitas formal dan informal baik di lingkungan gated maupun ungated community sekitarnya. Sementara rendahnya partisipasi sosial sangat dipengaruhi oleh karakteristik masyarakat yang cenderung individualis.

Nilai indeks kepercayaan sebesar 0.33 yang dapat dipahami bahwa masyarakat memiliki kepercayaan lebih tinggi terhadap orang yang dikenal dibandingan terhadap orang asing. Kepercayaan di dalam masyarakat the Taman Dayu sangat dipengaruhi oleh jaringan yang ada di dalam masyarakat. Masyarakat yang saling mengenal satu sama lain menciptakan persepsi bahwa tetangga yang tinggal di lingkungan yang sama merupakan pribadi yang baik.

Masyarakat the Taman Dayu bertimbal balik tidak hanya dalam interaksi dengan kelompok yang sama, tetapi juga dengan kelompok yang berbeda. Masyarakat saling berbalas kebaikan karena adanya norma yang dianut (nilai indeks resiprositas sebesar 0.67). Meskipun masyarakat cenderung tidak saling mengenal dan tidak memiliki ikatan keluarga, tetapi masih memiliki kepedulian terhadap sesama warga perumahan maupun masyarakat sekitarnya yang umumnya dilatarbelakangi oleh rasa kemanusiaan atau solidaritas. 


\section{Integrasi Sosial gated community the Taman Dayu}

Masyarakat the Taman Dayu memiliki nilai indikator pemisahan sosial dan spasial sebesar 0.33. Poin yang perlu mendapat perhatian adalah parameter perbedaan yang membagi masyarakat masih rendah, yaitu hanya sebesar 0.14 . Perbedaan yang cenderung membagi masyarakat diantaranya: pendidikan, kesejahteraan, agama, etnis dan lama tinggal (warga baru atau lama) serta ruang tempat tinggal (perumahan gated dan ungated community). Pemisahan spasial merupakan pemisahan yang paling banyak dinilai membagi masyarakat dalam kelompok tertentu (18.51\%).

Ditinjau dari aksesibilitas terhadap fasilitas, masyarakat the Taman Dayu memiliki nilai indikator aksesibilitas terhadap fasilitas yang rendah, yaitu sebesar 0.16. Rendahnya aksesibilitas masyarakat terutama disebabkan oleh rendahnya frekuensi aktivitas yang memanfaatkan fasilitas olahraga dan RTH atau taman di lingkungan permukiman masyarakat sekitar the Taman Dayu. Hal tersebut relevan jika dikaitkan dengan fasilitas perumahan the Taman Dayu yang memadai, termasuk ketersediaan fasilitas olahraga dan ruang publik seperti RTH maupun taman bermain. Fasilitas tersebut memiliki kondisi yang baik sehingga dapat dimanfaatkan oleh masyarakat dengan optimal dan sebagai hasilnya masyarakat the Taman Dayu umumnya merasa tidak membutuhkan fasilitas olahraga dan ruang publik di luar kawasan the Taman Dayu.

Secara umum hasil analisis integrasi sosial bermuara pada kesimpulan bahwa masyarakat the Taman Dayu memiliki integrasi sosial rendah dengan nilai indeks integrasi sosial sebesar 0.25 (tabel 3). Rendahnya integrasi sosial disebabkan banyaknya faktor yang dinilai dapat memisahkan masyarakat secara sosial dan spasial serta rendahnya frekuensi aktivitas yang memanfaatkan fasilitas olahraga, RTH, perdagangan dan peribadatan di lingkungan sekitar the Taman Dayu.

Tabel 3. Analisis Integrasi Sosial

\begin{tabular}{cc}
\hline \multicolumn{1}{c}{ Dimensi } & Nilai \\
\hline Sudut pandang terhadap pemisahan sosial dan spasial & 0.33 \\
Aksesibilitas terhadap fasilitas & 0.16 \\
\hline Nilai Indeks & $\mathbf{0 . 2 5}$ \\
\hline
\end{tabular}

Secara umum dapat disimpulkan bahwa telah terdapat integrasi sosial di dalam masyarakat the Taman Dayu. Meski demikian, beberapa temuan mengindikasikan masih ada bentuk segregasi yang berupa pemisahan sosial dan spasial. Pemisahan spasial ditunjukkan oleh pandangan masyarakat yang melihat perbedaan ruang tempat tinggal antara masyarakat gated dan ungated community. Masyarakat juga merasa dibedakan dari segi kesejahteraan dan etnis. Hal ini dapat dilihat dari pengelompokan masyarakat berdasarkan golongan sosial ekonomi yang mana masyarakat the Taman Dayu umumnya adalah golongan menengah ke atas, sedangkan masyarakat sekitarnya adalah golongan menengah ke bawah.

\section{Keberlanjutan Sosial gated community the Taman Dayu}

Keberlanjutan sosial dalam penelitian ini diikat oleh konteks hubungan masyarakat di dalam gated community dan dengan masyarakat di sekitarnya. Berdasarkan hasil analisis indeks komposit yang dapat dilihat pada tabel 4 diketahui keberlanjutan sosial gated community the Taman Dayu termasuk kategori sedang dengan nilai indeks keberlanjutan sosial sebesar 0.35 .

Gambar 4 menunjukkan posisi setiap dimensi dalam keberlanjutan sosial. Terlihat bahwa resiprositas merupakan dimensi yang berada pada titik tertinggi, yang berarti bahwa resiprositas masyarakat tinggi dalam konteks keberlanjutan sosial. Tingginya resiprositas 
masyarakat the Taman Dayu tidak terlepas dari norma dan harapan yang tinggi di dalam masyarakat. Meskipun keduanya diukur secara konseptual, tetapi tidak dapat dipungkiri bahwa ada faktor yang mendorong perilaku eksisting maupun di masa depan. Lebih lanjut keberadaan norma dan harapan yang tinggi di dalam masyakat dapat mendorong tumbuhnya perilaku resiprositas yang jika terjadi terus menerus mampu menumbuhkan kerjasama dan secara langsung meningkatkan modal dan integrasi sosial.

Tabel 4. Analisis Keberlanjutan Sosial

\begin{tabular}{ll}
\hline \multicolumn{1}{c}{ Dimensi } & Nilai \\
\hline Jaringan sosial & 0.26 \\
Kepercayaan & 0.33 \\
Resiprositas & 0.67 \\
Sudut pandang terhadap pemisahan sosial dan spasial & 0.33 \\
Aksesibilitas terhadap fasilitas & 0.16 \\
\hline \multicolumn{2}{c}{ Nilai Indeks } \\
\hline
\end{tabular}

Dimensi yang berada pada titik terendah adalah aksesibilitas terhadap fasilitas. Pada dasarnya telah ada kebijakan yang mengatur pemanfaatan fasilitas pada lingkungan atau kawasan gated community. Keberadaan fasilitas umum yang berada pada kawasan the Taman Dayu banyak dimanfaatkan oleh masyarakat sekitarnya. Namun karena lokasinya di dalam kawasan the Taman Dayu menyebabkan masyarakat the Taman Dayu tidak perlu ke luar dari kawasan gated community untuk dapat menggunakan fasilitas umum. Ketersediaan fasilitas di kawasan the Taman Dayu menyebabkan masyarakat the Taman Dayu tidak membutuhkan fasilitas di luar kawasan, sehingga umumnya tidak pernah menggunakan fasilitas di luar kawasan the Taman Dayu. Hal ini berdampak pada rendahnya integrasi sosial karena kurangnya interaksi bersama antar masyarakat the Taman Dayu dengan masyarakat sekitarnya, yang sebenarnya dapat diwadahi oleh ruangruang fasilitas umum.

Dimensi lain yang juga perlu mendapat perhatian adalah pemisahan sosial dan spasial. Terdapat banyak faktor pembeda yang memisahkan masyarakat, terutama secara spasial antara masyarakat the Taman Dayu dengan masyarakat sekitarnya. Pemisahan secara sosial ekonomi juga dinilai cukup siginifikan oleh masyarakat, terutama yang disebabkan oleh faktor kesejahteraan. Sebagaimana dijelaskan bahwa gated community seringkali merepresentasikan kelas sosial ekonomi menengah ke atas dengan gaya hidup modern dan individualis. Pada sisi lain terdapat masyarakat di luar gated community yang umumnya merupakan golongan menengah ke bawah. Hal ini menciptakan ruang yang berbeda antara masyarakat gated dan ungated community yang mewujud dalam bentuk segregasi atau pemisahan.

Segregasi dapat menyebabkan permasalahan sosial seperti disintegrasi dan konflik sosial. Lebih lanjut pemisahan tersebut berpontensi menghasilkan stratifikasi sosial yang berdampak pada munculnya ketimpangan spasial. Secara umum pemisahan merepresentasikan adanya ketimpangan baik di dalam gated community maupun antara gated dan ungated community di sekitarnya. Ketimpangan di dalam masyarakat the Taman Dayu ditunjukkan oleh adanya pemisahan spasial cluster-cluster perumahan yang didasarkan pada harga rumah. Hal tersebut berarti bahwa masyarakat di dalam gated community the Taman Dayu dipisahkan oleh perbedaan kesejahteraan atau dalam hal ini adalah daya beli terhadap jenis rumah yang berbeda. Pola yang sama juga menyebabkan ketimpangan antara masyarakat the Taman Dayu dan masyarakat sekitarnya.

Masyarakat the Taman Dayu menyadari ada pemisahan spasial dan sosial di dalam masyarakat dan hal ini tidak terlepas dari preferensi masyarakat dalam memilih lingkungan tempat tinggal. Meski demikian dengan adanya jaringan sosial di dalam masyarakat the Taman Dayu diharapkan dapat menumbuhkan kepercayaan dan resiprositas guna 
mencapai keberlanjutan sosial. Pada akhirnya homogenitas dalam kelompok masyarakat dan heterogenitas antar kelompok masyarakat dapat menjadi potensi sekaligus kendala. Semakin homogen karakteristik dalam masyarakat maka komunikasi yang terjalin akan semakin baik dan efektif. Meski demikian kondisi ini tidak banyak dijumpai pada masyarakat the Taman Dayu. Kesamaan karakteristik sosial ekonomi tidak serta merta menjadi faktor pendorong interaksi antar masyarakat di dalam gated community.

Secara umum dapat disimpulkan bahwa keberlanjutan sosial gated community masih perlu ditingkatkan untuk mencegah terjadinya ketimpangan sosial. Dimensi yang perlu menjadi perhatian utama adalah jaringan sosial, kepercayaan dan sudut pandang terhadap pemisahan sosial dan spasial serta aksesibilitas terhadap fasilitas.

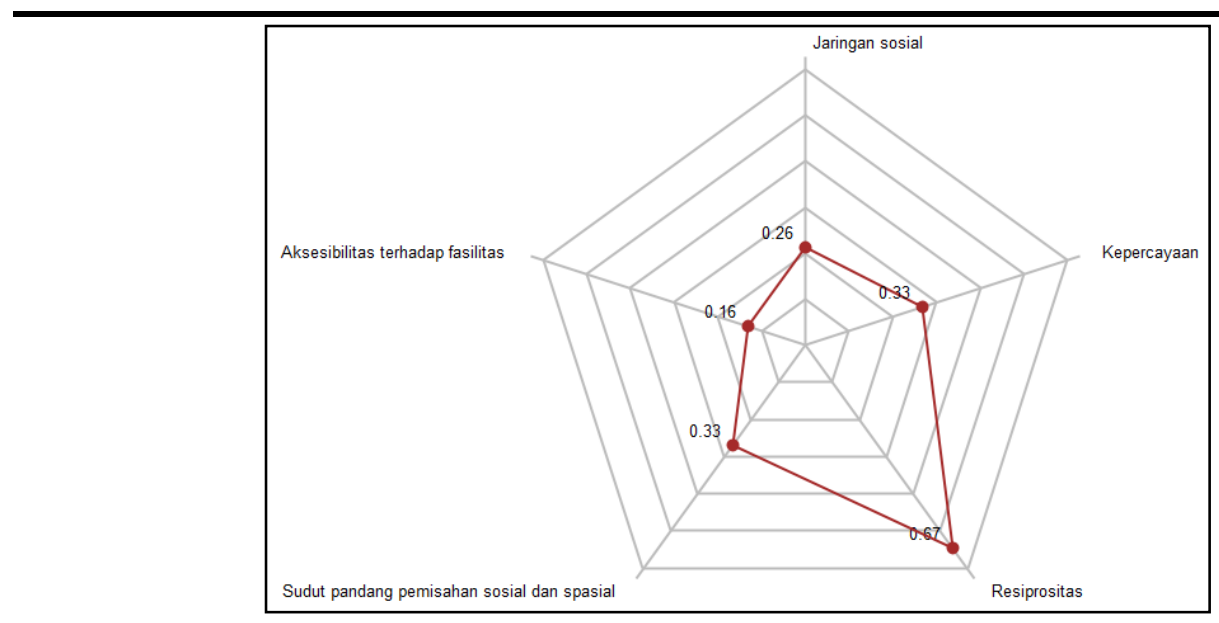

Sumber: Hasil Analisis, 2018

\section{Gambar 4. Dimensi Keberlanjutan Sosial}

\section{KESIMPULAN}

Keberadaan gated community the Taman Dayu sebagai salah satu fenomena pembangunan perumahan cukup menarik untuk dikaji. Karakteristik the Taman Dayu yang secara fisik lingkungan memiliki fungsi 'pemagaran' dan limitasi akses, serta secara sosial ekonomi merupakan golongan menengah ke atas merepresentasikan adanya segregasi dan ketimpangan baik antar masyarakat the Taman Dayu maupun dengan masyarakat sekitarnya.

Keberlanjutan sosial gated community the Taman Dayu termasuk kategori sedang yang berarti bahwa telah ada modal dan integrasi sosial di dalam masyarakat the Taman Dayu, tetapi keberadaannya masih perlu ditingkatkan. Masyarakat saling berinteraksi, membangun jaringan dan bekerjasama tetapi tidak setiap rumah tangga terlibat.

Upaya-upaya yang dapat mendorong keberlanjutan sosial gated community the Taman Dayu diperlukan guna mencegah berbagai permasalahan sosial seperti ketimpangan, segregasi dan ketegangan sosial. Upaya tersebut diantaranya berupa meningkatkan partisipasi masyarakat dalam berbagai komunitas sosial dan kegiatan publik. Hal ini dapat dilakukan dengan penerapan program-program yang bersifat bottom-up sebagai sarana saling mengenal, berinteraksi dan membangun serta memperluas jaringan sosial. Hal tersebut juga akan berdampak pada tumbuhnya kepercayaan dalam masyarakat.

Mengintegreasikan kebijakan terkait gated community dengan kebijakan tata ruang juga penting dilakukan sebagai upaya untuk mendorong keberlanjutan sosial gated community. Upaya ini dapat dilakukan dengan mengintegrasikan pembangunan 
perumahan dengan unsur-unsur lokalitas wilayah. Selain itu, Pembatasan desain tapak kawasan perumahan diperlukan dengan menyesuaikannya dengan kaidah keberlanjutan sosial mengingat perumahan yang dibangun pengembang seringkali mengedepankan eksklusifitas dan limitasi aksesibilitas yang dapat menciptakan segregasi dan ketimpangan spasial. Pengaturan penyediaan dan pengelolaan fasilitas kawasan perumahan juga sebaiknya tidak selalu berada di dalam kawasan perumahan yang dibangun oleh pengembang, tetapi dapat berada di luar kawasan sehingga memungkinkan masyarakat saling berbagi fasilitas bersama yang selanjutnya dapat menciptakan integrasi sosial.

\section{UCAPAN TERIMAKASIH}

Penulis mengucapkan terimakasih kepada Lembaga Pengelola Dana Pendidikan (LPDP) atas dukungan finansial yang diberikan untuk penelitian ini.

\section{DAFTAR PUSTAKA}

Atkinson, R., \& Blandy, S. (2005). Introduction: International Perspectives on The New Enclavism and the Rise of Gated Communities. Housing Studies, 20(2), 177-186. https://doi.org/10.1080/0267303042000331718

Baffoe, G., \& Mutisya, E. (2015). Social sustainability: a review of indicators and empirical application. Environmental Management and Sustainable Development, 4(2), 242. https://doi.org/10.5296/emsd.v4i2.8399

Baum, F., C, M., Palmer, C., Murray, C., \& Bush, R. (2000). Families, social capital and health (pp. 250-275). Melbourne: Australian Institute of Family Studies.

Cruz-Saco, M. A. (2008). Promoting Social Integration: Economic, Social and Political Dimensions with a focus on Latin America.

Fukuyama, F. (1995). Trust: The social virtues and the creation of prosperity. Free Press Paperbacks.

Grant, J., \& Mittelsteadt, L. (2004). Types of gated communities. Environment and Planning B: Planning and Design, 31(6), 913-930. https://doi.org/10.1068/b3165

Ibrahim, L. D. (2006). Memanfaatkan modal sosial komunitas lokal dalam program kepedulian korporasi. Jurnal Filantropi Dan Masyarakat Madani GALANG, 1(2), 19-28.

Krishna, A., \& Shrader, E. (1999). Social capital assessment tool, 1-21.

Munandar, S. M. (2001). Ilmu Sosial Dasar: teori dan konsep. Bandung: Refika Aditama.

Onyx, J., \& Bullen, P. (2000). Measuring Social Capital in Five Communities. The Journal of Applied Behavioral Science, 36(1), 23-42. https://doi.org/10.1177/0021886300361002

Putnam, R. D. (1993). The prosperous community. The American Prospect, 4(13), 35-42.

PT. Ciputra Development Tbk. (2017). Masterplan the Taman Dayu. PT. Ciputra Development Tbk, Pasuruan.

Roitman, S. (2010). Gated communities: definitions, causes and consequences. In Gated Communities: definitions, causes and concequences (pp. 31-38).

Salcedo, R., \& Torres, A. (2002). Gated Communities: Wall or Frontier?, 28(March), 27-45.

Stone, W. (2001). Measuring social and community life, (24).

Surjono, Sudikno, A., \& Ridhoni, M. (2017). Lessons learnt from and sustainability assessment of Indonesian urban kampong. IOP Conference Series: Earth and Environmental Science, 70(1). https://doi.org/10.1088/1755-1315/70/1/012061

Vesselinov, E., Cazessus, M., \& Falk, W. (2007). Gated communities and spatial inequality. Journal of Urban Affairs, 29(2), 109-127. https://doi.org/10.1111/j.1467-9906.2007.00330.x

Widhyharto, D. S. (2009). Komunitas Berpagar: Antara Inovasi Sosial dan Ketegangan Sosial (Studi Kasus Komunitas Berpagar di Propinsi D.I Yogyakarta, Indonesia). JSP (Jurnal Ilmu Sosial Dan Ilmu Politik), 13(2), 204-230. https://doi.org/10.22146/JSP.10962

Yuliastuti, N., \& Tanjung, adinda sekar. (2011). Pengaruh Jalan Lingkungan Sebagai Ruang Interaksi Sosial Terhadap Lingkungan Permukiman Bungur, Jakarta Pusat. Tataloka, 13(3), 190-196. 